\title{
Analysis of Coseismic Fault Slip Models of the 2012 Indian Ocean Earthquake: Importance of GPS Data for Crustal Deformation Studies
}

\author{
Endra GUNAWAN ${ }^{1}$, Putra MAULIDA ${ }^{2}$, Irwan MEILANO ${ }^{2,3}$, \\ Masyhur IRSYAM ${ }^{3}$, and Joni EFENDI ${ }^{4}$ \\ ${ }^{1}$ Graduate Research on Earthquake and Active Tectonics, Faculty of Earth Science \\ and Technology, Bandung Institute of Technology, Bandung, Indonesia \\ e-mail: endra@lppm.itb.ac.id \\ ${ }^{2}$ Geodesy and Geomatics Engineering, Faculty of Earth Science and Technology, \\ Bandung Institute of Technology, Bandung, Indonesia \\ ${ }^{3}$ Research Center for Disaster Mitigation, Bandung Institute of Technology, \\ Bandung, Indonesia \\ ${ }^{4}$ Geospatial Information Agency, Cibinong, Indonesia
}

\begin{abstract}
Based on continuous GPS data, we analyze coseismic deformation due to the 2012 Indian Ocean earthquake. We use the available coseismic slip models of the 2012 earthquake, derived from geodetic and/or seismic waveform inversion, to calculate the coseismic displacements in the Andaman-Nicobar, Sumatra and Java. In our analysis, we employ a spherical, layered model of the Earth and we find that Java Island experienced coseismic displacements up to $8 \mathrm{~mm}$, as also observed by our GPS network. Compared to coseismic offsets measured from GPS data, a coseismic slip model derived from multiple observations produced better results than a model based on a single type of observation.
\end{abstract}

Key words: the 2012 Indian Ocean earthquake, coseismic deformation, GPS displacement.

Ownership: Institute of Geophysics, Polish Academy of Sciences;

(C) 2016 Gunawan et al. This is an open access article distributed under the Creative Commons Attribution-NonCommercial-NoDerivs license,

http://creativecommons.org/licenses/by-nc-nd/3.0/. 


\section{INTRODUCTION}

On 11 April 2012, a $M_{w} 8.6$ Indian Ocean earthquake (IOE) occurred $300 \mathrm{~km}$ west of the Sunda trench (Meng et al. 2012). It was part of an earthquake sequence which involved a preshock of $M_{w} 7.3$ on 10 January 2012, a mainshock of $M_{w} 8.6$ on 11 April 2012, and an aftershock of $M_{w} 8.2$ two hours after the mainshock (Duputel et al. 2012). Considered to be the largest known strike-slip intraplate earthquake event, it has been suggested that the 2012 IOE occurred as a result of stress transfer after the $2004 M_{w} 9.2$ Sumatra-Andaman earthquake and the $2005 M_{w} 8.7$ Nias earthquake (Delescluse $e t$ al. 2012). The Indonesian Agency for Meteorology, Climatology and Geophysics (BMKG) reported that aftershock of $M>3$ occurred practically continuously, with up to 400 events registered for six months after the $2012 \mathrm{IOE}$ (Fig. 1).

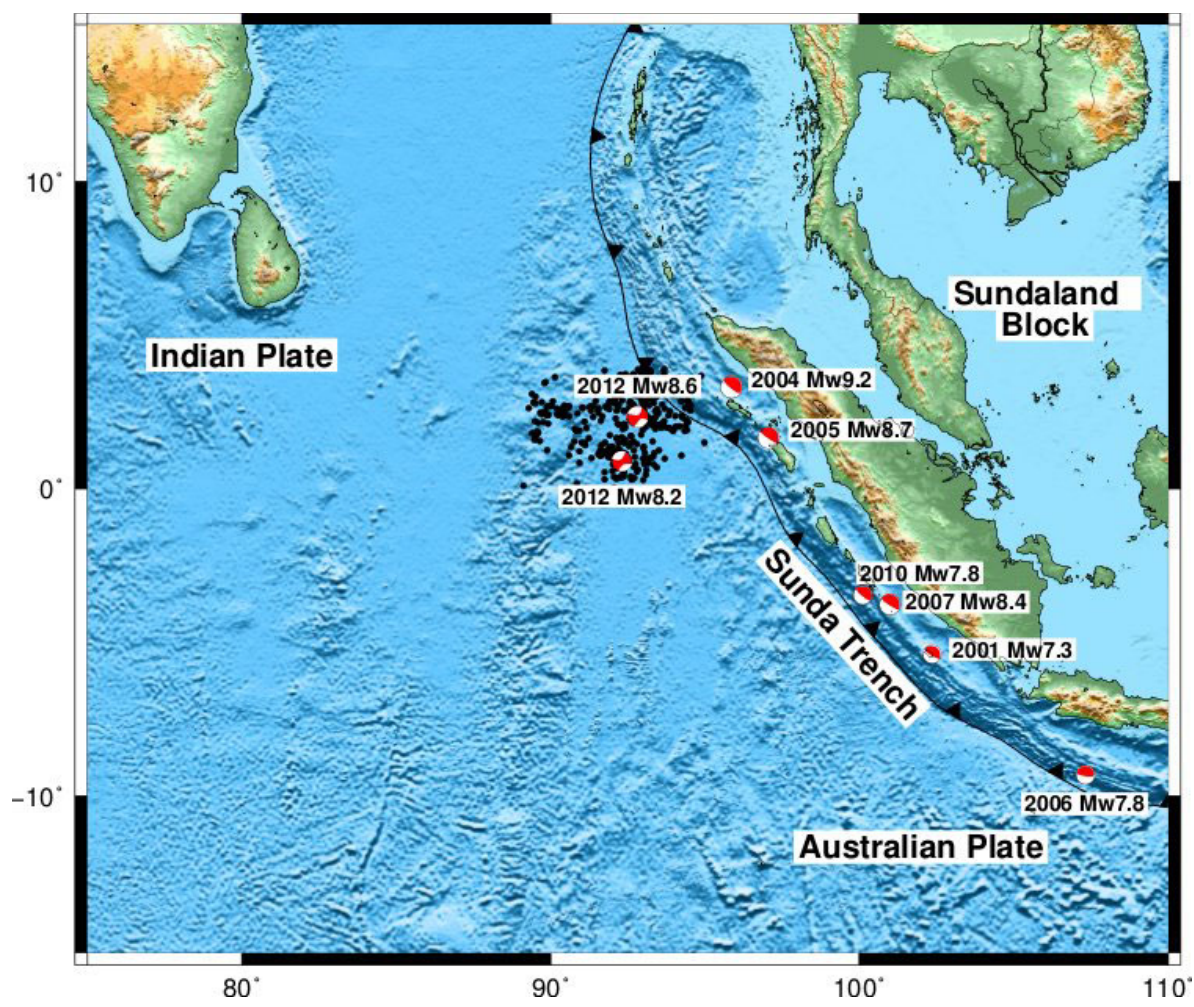

Fig. 1. Tectonic background of this study. Beach balls represent earthquake occurrences offshore the western side of northern Sumatra over the last decade from the Global CMT catalogue. Black dots indicate six-month aftershocks of the 2012 IOE based on the Indonesian Agency for Meteorology, Climatology and Geophysics (BMKG) catalogue. 
Global Positioning System (GPS) data are an indispensable tool for analyzing the crustal deformation of the Earth. Previous crustal deformation studies, such as those of fault slip rate (Ito et al. 2012), fault coupling (Hanifa et al. 2014, Ohkura et al. 2015), coseismic and postseismic deformation (Gusman et al. 2015, Ito et al. 2016, Gunawan et al. 2016a, Alif et al. 2016), and aseismic slip after earthquake occurrences (Ardika et al. 2015, Raharja et al. 2016), inferring rheological models (Gunawan et al. 2014) and use of deformation for seismic hazard analysis (Meilano et al. 2015), have shown that GPS can be used comprehensively for crustal deformation analysis.

We utilize and compile all available GPS data sets associated with the coseismic deformation of the 2012 IOE, which have been previously reported in studies of Andaman-Nicobar (Yadav et al. 2013) and Sumatra (Feng et al. 2015). Also, we report additional GPS data from stations located in Java and along Sumatra that have not been reported so far.

Using these complete GPS sets, this study investigates the response of various available finite fault models of the 2012 IOE, namely by Hayes (http://earthquake.usgs.gov/earthquakes/eqinthenews/2012/usc000905e/finit

e_fault.php; accessed on December 2015), hereinafter referred to as the H12 model, by Yue et al. (2012), hereinafter referred to as the Y12 model; by Wei et al. (2013), hereinafter referred to as the W13 model; and by Hill et al. (2015), hereinafter referred to as the H15 model. We investigate how well these models fit to the observed coseismic offsets as derived from GPS data. Investigation of the best coseismic slip model is very crucial, especially in analyzing postseismic deformation after earthquake occurrences. In addition, understanding the distribution of coseismic slip during earthquake occurrences will greatly improve further hazard analysis.

\section{COSEISMIC SLIP MODEL}

Similar to other earthquakes of magnitude 8 or more, the $2012 M_{w} 8.6$ IOE has attracted investigation of crustal deformation associated with this intraplate earthquake. In order to invert the coseismic slip of the 2012 IOE, previous studies have used geodetic and/or seismic data. The H12 model used 38 teleseismic broadband $P$ waveforms, 13 broadband $S H$ waveforms, and 56 long-period surface waves to analyze the coseismic slip of the 2012 IOE. It was inferred that multiple faults were involved in the rupture. This suggested that a NNE-SSW fault plane with a strike of $199^{\circ}$ and a WNW-ESE fault plane with a strike of $108^{\circ}$ ruptured during this earthquake, with a maximum slip of $70 \mathrm{~m}$ (Fig. 2).

The Y12 model analyzed the 2012 IOE using short-period body waves and long-period surface waves recorded at teleseismic stations; it was suggested that rupture involved a very complex network of faults that had never 

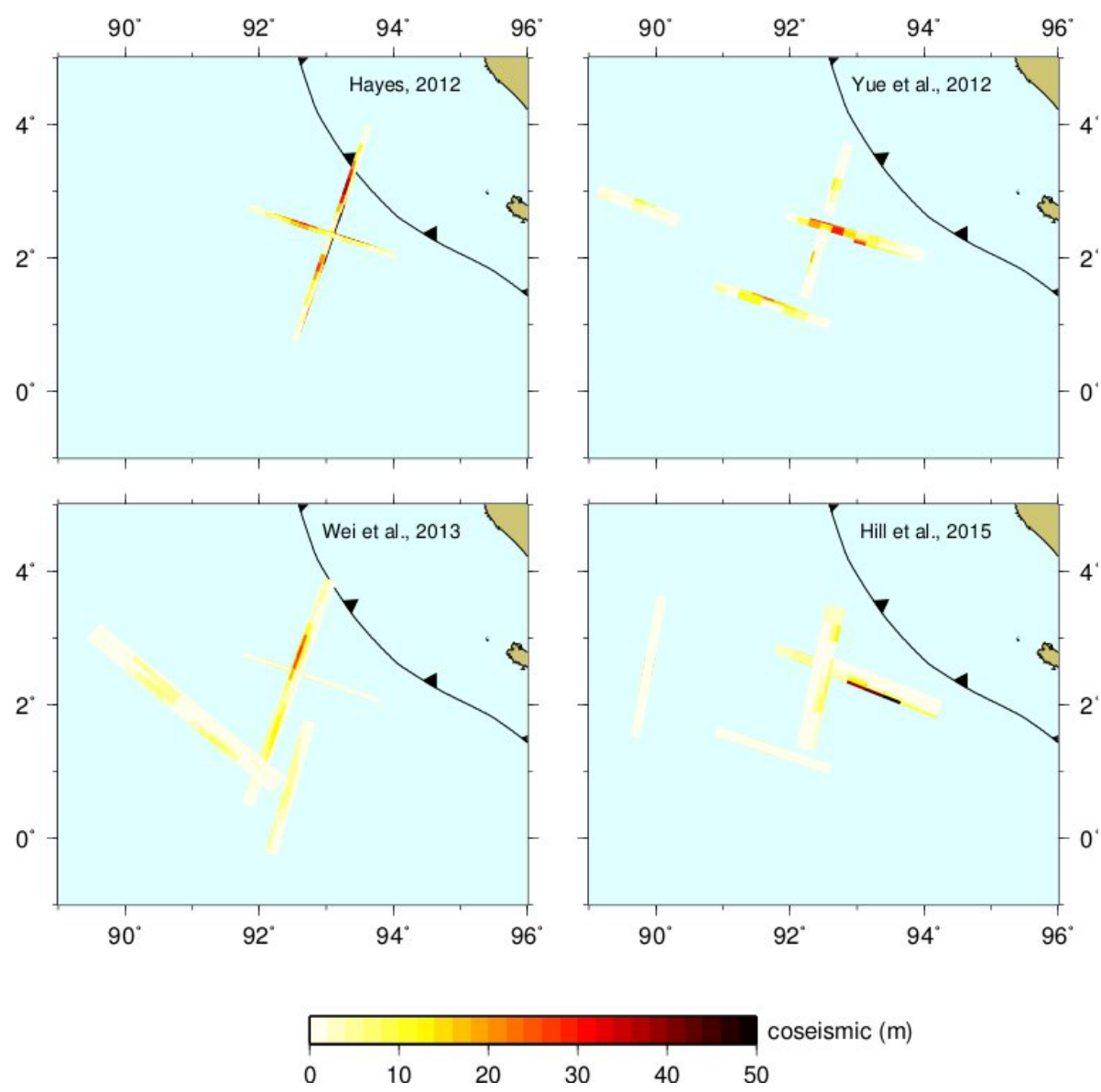

Fig. 2. Coseismic slip models of the 2012 IOE used in this study based on the results of Hayes (USGS), Yue et al. (2012), Wei et al. (2013), and Hill et al. (2015).

been documented or mapped before. They showed that the first fault, with WNW-ESE orientation, ruptured with seismic moment of $\sim M_{w} 8.5$, triggering the cross-cutting, orthogonal second fault in the NNE-SSW direction with seismic moment of $\sim M_{w} 7.9$. Then, the third fault in the direction of WNWESE ruptured with seismic moment of $\sim M_{w} 8.3$, at about $150 \mathrm{~km}$ southwest of the first fault. Finally, the fourth fault in the WNW-ESE direction, at about $330 \mathrm{~km}$ from the epicenter, ruptured with seismic moment of $\sim M_{w} 7.8$. The total rupture at these faults corresponds to a seismic moment of $\sim M_{w} 8.7$ (Fig. 2).

The W13 model analyzed coseismic slip of the 2012 IOE earthquakes using joint inversion of regional and teleseismic waveform data, showing 
that the rupture started on an ESE-WNW fault with a strike of $289^{\circ}$, which produced a maximum slip of $12 \mathrm{~m}$. Then, after $10 \mathrm{~s}$, rupture continued on a $20^{\circ}$ strike fault with maximum slip of $24 \mathrm{~m}$. The third rupture occurred $70 \mathrm{~s}$ later, with a maximum slip of $8 \mathrm{~m}$ on a $310^{\circ}$ strike fault. They showed that two hours after the mainshock, a $M_{w} 8.2$ earthquake occurred along a $16^{\circ}$ strike fault with a maximum slip of $6.5 \mathrm{~m}$ (Fig. 2).

The H15 model used joint inversion of high-rate GPS data, far-field static GPS displacements, teleseismic observations and source time functions derived from broadband surface waves to analyze the 2012 IOE. They showed that most of the moment release was along the WNW-ESE rightlateral fault plane with a maximum slip of $48 \mathrm{~m}$. Their result suggests that multiple faults ruptured during the event, including a NNE-SSW fault at $400 \mathrm{~km}$ west of the hypocenter (Fig. 2).

Because these studies used different methodologies and data, their results yield very different coseismic slip models. For example, the coseismic slip models of $\mathrm{H} 12$ and $\mathrm{W} 13$ considered the main rupture as occurring on a NNE-SSW fault, while the Y12 and H15 models considered the WNW-ESE fault to be the main rupture. Maximum slips obtained by these studies also differ, with the H12 coseismic fault model producing the highest maximum slip, followed by the H15, Y12, and W13 models.

\section{GPS DATA AND METHOD}

This study utilizes GPS data from stations surrounding the epicenter of the 2012 IOE, located in the Andaman-Nicobar region, Sumatra, and Java (Fig. 3). Some of these GPS data are obtained from previous studies, namely those reported by Yadav et al. (2013) and Feng et al. (2015). In addition to these available GPS data, we also use new GPS data sets from stations located in Sumatra and Java as part of the Indonesian Continuously Operating Reference Stations (InaCORS). Table 1 summarizes the GPS sites used in this study.

Yadav et al. (2013) reported the coseismic offsets of the 2012 IOE observed by the Andaman-Nicobar Permanent GPS Network (ANPGN). They showed that GPS sites in the Andaman Islands, which are located to the north of 2012 IOE, experienced southward movement with coseismic displacements up to $3 \mathrm{~cm}$. The GPS site located at Nicobar Island experienced coseismic displacement of $4 \mathrm{~cm}$ in the southeast direction (Fig. 4).

GPS sites along Sumatra Island also experienced coseismic displacements during the 2012 IOE. Feng et al. (2015) pointed out that the SuGAr (Sumatran GPS Array) recorded significant offsets from the 2012 IOE, showing that Simeuleu Island experienced the largest coseismic offsets, up to $28 \mathrm{~cm}$. The GPS network in northern Sumatra, named the Aceh GPS Net- 

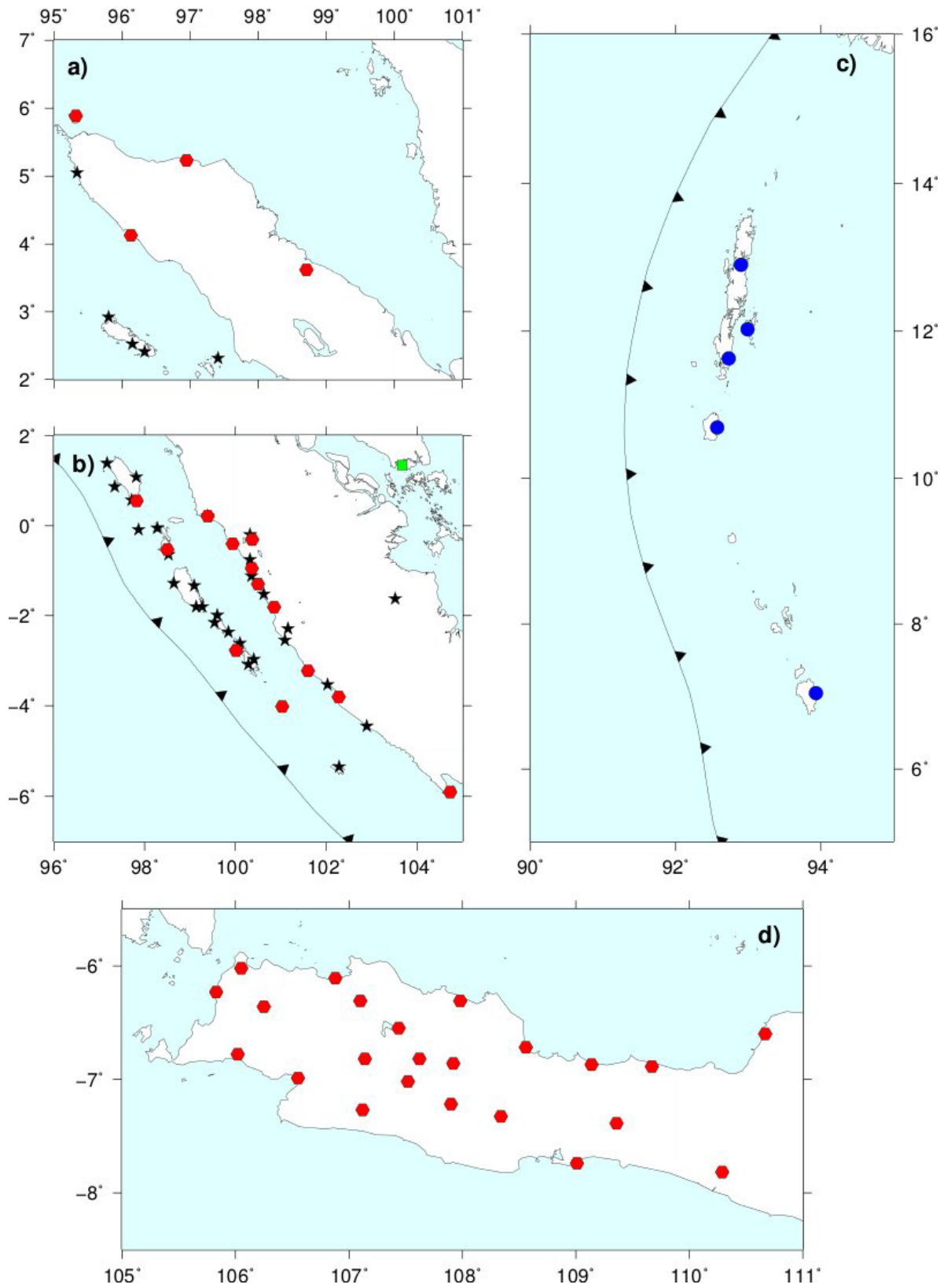

Fig. 3. Locations of GPS sites used in this study. Blue circles indicate GPS sites at Andaman-Nicobar from Yadav et al. (2013), black stars denote GPS sites of the SuGAr (Feng et al. 2015) and red hexagons and green squares represent GPS sites of BIG and IGS, respectively. 
Table 1

Information about the GPS sites used in this study

\begin{tabular}{|c|c|c|c|c|c|c|c|}
\hline Site & $\begin{array}{c}\text { Long. } \\
{\left[{ }^{\circ}\right]}\end{array}$ & $\begin{array}{c}\text { Lat. } \\
{\left[{ }^{\circ}\right]}\end{array}$ & Network & Site & $\begin{array}{c}\text { Long. } \\
{\left[{ }^{\circ}\right]}\end{array}$ & $\begin{array}{c}\text { Lat. } \\
{\left[{ }^{\circ}\right]}\end{array}$ & Network \\
\hline ABGS & 99.39 & 0.22 & $\mathrm{uGAr}^{1}$ & MLBU & 100.85 & -1.81 & InaCORS \\
\hline BITI & 97.81 & 1.08 & $\mathrm{IGAr}^{1}$ & SAMP & 98.71 & 3.62 & InaCORS $^{2}$ \\
\hline BNON & 96.15 & 2.52 & & SEBL & 101.60 & -3.22 & InaCORS $^{2}$ \\
\hline BSAT & 100.28 & -3.08 & & SLBI & 100.01 & -2.77 & \\
\hline BSIM & 96.33 & 2.41 & & TDAL & 97.82 & 0.55 & \\
\hline BTET & 98.64 & -1.28 & & TIKU & 99.94 & -0.40 & InaCORS $^{2}$ \\
\hline BTHL & 97.71 & 0.57 & & TLOK & 100.50 & -1.30 & \\
\hline BUKT & 100.32 & -0.20 & & TNBL & 98.50 & -0.53 & \\
\hline HNKO & 7.34 & 0.87 & & CBAY & 93.93 & 7.05 & \\
\hline JMBI & 103.52 & -1.62 & & HBAY & 92.57 & 10.69 & \\
\hline KTET & 99.84 & -2.36 & & PORT & 92.73 & 11.63 & $\mathrm{GN}^{3}$ \\
\hline LAIS & 102.03 & -3.53 & & HAVE & 92.99 & 12.0 & \\
\hline LEWK & 95.80 & 2.92 & & MBDR & 92.90 & 12.9 & \\
\hline LHW2 & 97.17 & 1.39 & & PALK & 80.70 & 7.27 & \\
\hline LNNG & 101.16 & -2.29 & & $\mathrm{COCO}$ & 96.83 & 12.1 & \\
\hline MKMK & 10 & -2.54 & & BAKO & 106.84 & 6.4 & \\
\hline MLKN & 102.28 & -5.35 & & XMIS & 105.68 & 10. & $\mathrm{IGS}^{3}$ \\
\hline MNNA & 102.89 & -4.45 & & $\mathrm{CU}$ & 100.53 & 13.74 & IGS $^{3}$ \\
\hline MSAI & 99 & -1.33 & & DGAR & 72.37 & 7.26 & IG \\
\hline NGNG & 99.27 & -1.80 & & CANG & 107.52 & -7.02 & $\mathrm{RS}^{2}$ \\
\hline NTUS & 103.67 & 1.346 & & CBTU & 107.10 & -6 & InaCORS $^{2}$ \\
\hline PARY & & -0.75 & $\mathrm{SuGAr}^{1}$ & CCIR & 108.56 & -6.7 & InaCORS $^{2}$ \\
\hline PBJO & & -0.64 & & CCLP & 109.01 & -7.7 & \\
\hline PBLI & 97.41 & 2.31 & $\mathrm{uG}$ & CGON & 106.05 & -6.0 & $\mathrm{CORS}^{2}$ \\
\hline PKRT & & -2.15 & SuGAr ${ }^{1}$ & CJKT & 106.88 & -6.11 & InaCORS $^{2}$ \\
\hline PPNJ & & -1.99 & & CJPR & 110.67 & -6.60 & \\
\hline PRKB & & -2.97 & & CJUR & & -6.82 & \\
\hline PSKI & 100.35 & -1.12 & $\mathrm{SuGAr}^{1}$ & CLBG & 107.62 & -6.82 & InaCORS $^{2}$ \\
\hline PSMK & & -0.09 & SuGAr ${ }^{1}$ & CMIS & 108.34 & -7.33 & InaCORS $^{2}$ \\
\hline PTLO & 98.28 & -0.05 & & CMLP & 106.02 & -6.7 & \\
\hline SLBU & & -2.77 & & CPBL & 109.36 & -7.39 & \\
\hline SMGY & 100.10 & -2.61 & $\mathrm{SuGAr}^{1}$ & CPKL & 109.67 & -6.89 & InaCORS $^{2}$ \\
\hline TLLU & 99.13 & -1.80 & $\mathrm{SuGAr}^{1}$ & CPSR & 105.83 & -6.23 & InaCORS $^{2}$ \\
\hline
\end{tabular}


Table 1 (continuation)

\begin{tabular}{|c|c|c|c||c|c|c|c|}
\hline Site & $\begin{array}{c}\text { Long. } \\
\left.{ }^{\circ}\right]\end{array}$ & $\begin{array}{c}\text { Lat. } \\
{\left[{ }^{\circ}\right]}\end{array}$ & Network & Site & $\begin{array}{c}\text { Long. } \\
{\left[{ }^{\circ}\right]}\end{array}$ & $\begin{array}{c}\text { Lat. } \\
{\left[{ }^{\circ}\right]}\end{array}$ & Network \\
\hline TRTK & 100.62 & -1.52 & SuGAr $^{1}$ & CPTU & 106.55 & -6.99 & InaCORS $^{2}$ \\
UMLH & 95.34 & 5.05 & SuGAr $^{1}$ & CPWK & 107.44 & -6.55 & InaCORS $^{2}$ \\
CAIR & 99.39 & 0.21 & InaCORS $^{2}$ & CRKS & 106.25 & -6.36 & InaCORS $^{2}$ \\
CBKL & 102.27 & -3.80 & InaCORS $^{2}$ & CROL & 107.98 & -6.31 & InaCORS $^{2}$ \\
CBKT & 100.37 & -0.31 & InaCORS $^{2}$ & CRUT & 107.90 & -7.22 & InaCORS $^{2}$ \\
CPDG & 100.36 & -0.95 & InaCORS $^{2}$ & CSUM & 107.92 & -6.86 & InaCORS $^{2}$ \\
CSAB & 95.32 & 5.89 & InaCORS $^{2}$ & CTAN & 107.12 & -7.27 & InaCORS $^{2}$ \\
CTCN & 104.73 & -5.91 & InaCORS $^{2}$ & CTGL & 109.14 & -6.87 & InaCORS $^{2}$ \\
LHMI & 96.95 & 5.23 & InaCORS $^{2}$ & JOGS & 110.29 & -7.82 & InaCORS $^{2}$ \\
MEGO & 101.03 & -4.01 & InaCORS $^{2}$ & HYDE & 17.42 & 78.55 & IGS $^{2}$ \\
MEUL & 96.13 & 4.13 & InaCORS $^{2}$ & IISC & 13.02 & 77.57 & IGS $^{2}$ \\
\hline
\end{tabular}

${ }^{1}$ Feng et al. (2015)

${ }^{2}$ This study

${ }^{3}$ Yadav et al. (2013)

work for the Sumatran fault System (AGNeSS; Tabei et al. 2015), was also affected by the 2012 IOE (Anugrah et al. 2015; Fig. 4).

In addition to the published data sets described above, we use the GPS network in Java and Sumatra installed and maintained by the Geospatial Information Agency of Indonesia (BIG). To analyze the daily coordinate solutions from these GPS sites, we use the GAMIT/GLOBK software package (Herring et al. 2010a,b). We process these GPS data together with several International GNSS Service (IGS) sites - DGAR, HYDE, IISC, COCO, XMIS, CUSV, KUNM, PIMO, GUAM, DARW, TOW2, KARR, TNML, and YAR2 - and tied the solutions into the International Terrestrial Reference Frame (ITRF) 2008 (Altamimi et al. 2011).

Our analysis indicates that GPS sites in Java experienced coseismic displacements up to $8 \mathrm{~mm}$ in the northwest direction (Fig. 4). The standard deviation obtained in our solution for each GPS site was about $4 \mathrm{~mm}$. Table 2 summarizes the coseismic displacements from the 2012 IOE at the GPS sites used in this study.

Using the available coseismic slip models - H12, Y12, W13, and H15 we calculate the modeled surface coseismic displacements based on a spherical, layered model of the Earth (Pollitz 1996) with elastic thickness of $65 \mathrm{~km}$ and Maxwell viscosity of $8.0 \times 10^{18} \mathrm{~Pa} \cdot \mathrm{s}$ (Gunawan et al. 2014). Modeled surface displacements calculated using the coseismic slip models H12, Y12, W13, and H15 are compared to the observed displacements from 

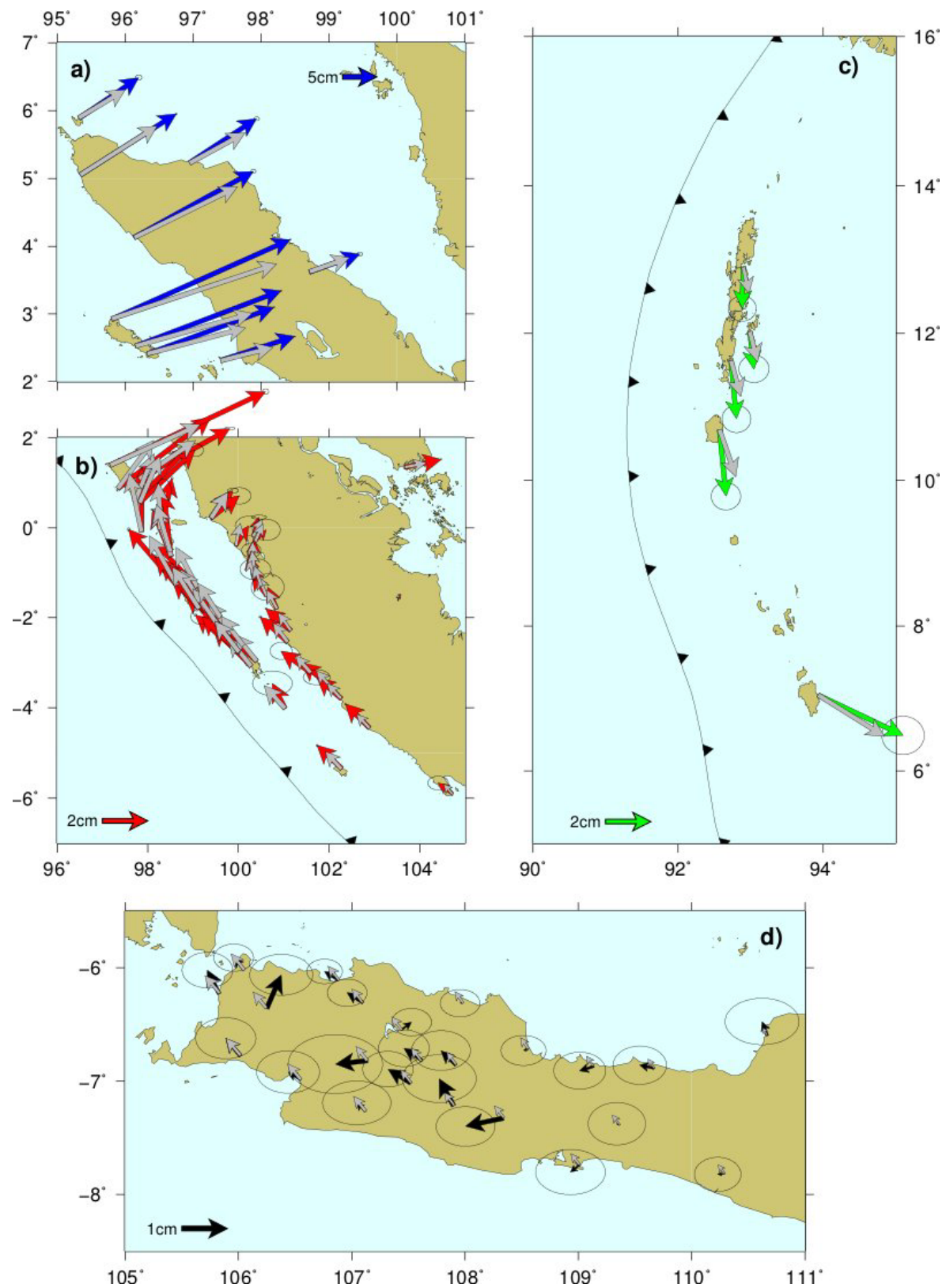

Fig. 4. Modeled displacements (gray arrows) calculated using the coseismic slip model of Hill et al. (2015) and observed coseismic displacements of the 2012 IOE at (a) northern Sumatra, indicated by blue arrows; (b) southern Sumatra, indicated by red arrows; (c) Andaman-Nicobar, indicated by green arrows; and (d) Java, indicated by black arrows. 
Table 2

Coseismic displacements of the 2012 IOE at GPS sites

\begin{tabular}{|c|c|c|c|c|c|c|c|c|c|}
\hline Site & $\begin{array}{c}E \\
{[\mathrm{~mm}]}\end{array}$ & $\begin{array}{c}N \\
{[\mathrm{~mm}]}\end{array}$ & $\sigma_{\mathrm{E}}$ & $\sigma_{\mathrm{N}}$ & Site & $\begin{array}{c}E \\
{[\mathrm{~mm}]}\end{array}$ & $\begin{array}{c}N \\
{[\mathrm{~mm}]}\end{array}$ & $\sigma_{\mathrm{E}}$ & $\sigma_{\mathrm{N}}$ \\
\hline ABGS & 9.8 & 12.0 & 1.6 & 0.7 & MLBU & -4.1 & 9.7 & 4.8 & 3.9 \\
\hline BITI & 40.0 & 22.3 & 1.5 & 0.4 & SAMP & 74.4 & 26.5 & 2.5 & 1.9 \\
\hline BNON & 214.4 & 81.6 & 0.8 & 0.5 & SEBL & -13.2 & 9.6 & 3.2 & 2.5 \\
\hline BSAT & -16.9 & 17.1 & 0.4 & 0.3 & SLBI & -16.4 & 15.8 & 3.2 & 2.3 \\
\hline BSIM & 185.6 & 68.4 & 0.9 & 0.5 & TDAL & 24.4 & 23.3 & 2.5 & 1.9 \\
\hline BTET & -21.3 & 24.7 & 0.4 & 0.4 & TIKU & 5.7 & 8.8 & 3.9 & 2.8 \\
\hline BTHL & 24.7 & 24.8 & 0.5 & 0.3 & TLOK & -2.5 & 7.5 & 4.5 & 3.1 \\
\hline BUKT & 2.7 & 8.6 & 2.2 & 0.6 & TNBL & -3.0 & 26.3 & 2.2 & 3.8 \\
\hline HNKO & 40.9 & 31.5 & 0.6 & 0.5 & CBAY & 37.5 & -17.8 & 6.2 & 5.6 \\
\hline JMBI & 0.9 & 2.5 & 0.3 & 0.2 & HBAY & 2.9 & -29.4 & 4.3 & 4.0 \\
\hline KTET & -20.3 & 17.1 & 0.4 & 0.4 & PORT & 2.4 & -25.7 & 4.2 & 4.0 \\
\hline LAIS & -12.6 & 10.6 & 0.3 & 0.2 & HAVE & 1.8 & -16.6 & 4.4 & 4.0 \\
\hline LEWK & 262.8 & 117.4 & 1.0 & 0.5 & MBDR & -0.5 & -18.3 & 4.1 & 3.7 \\
\hline LHW2 & 68.6 & 32.5 & 0.9 & 0.8 & PALK & -0.5 & -4.9 & 4.0 & 3.6 \\
\hline LNNG & -11.0 & 9.7 & 0.3 & 0.2 & $\mathrm{COCO}$ & -4.9 & 16.1 & 4.2 & 3.8 \\
\hline MKMK & -12.2 & 11.1 & 0.3 & 0.3 & BAKO & -4.2 & 1.8 & 4.6 & 4.0 \\
\hline MLKN & -10.9 & 10.3 & 0.3 & 0.3 & XMIS & -4.4 & 5.1 & 4.1 & 3.8 \\
\hline MNNA & -10.6 & 10.6 & 0.2 & 0.2 & CUSV & 3.4 & 5.0 & 4.4 & 4.0 \\
\hline MSAI & -18.8 & 20.0 & 0.3 & 0.2 & DGAR & -10.3 & -5.3 & 4.7 & 4.1 \\
\hline NGNG & -19.9 & 20.9 & 0.4 & 0.3 & CANG & -5.0 & 3.1 & 3.7 & 2.6 \\
\hline NTUS & 16.0 & 3.4 & 0.2 & 0.2 & CBTU & -3.5 & 2.2 & 2.9 & 2.0 \\
\hline PARY & 0.5 & 10.0 & 0.4 & 0.3 & CCIR & -1.1 & -0.3 & 3.3 & 2.2 \\
\hline PBJO & -8.4 & 20.7 & 0.4 & 0.3 & CCLP & -2.0 & -1.6 & 5.1 & 3.3 \\
\hline PBLI & 108.5 & 35.3 & 0.6 & 0.4 & CGON & -2.3 & 2.7 & 2.9 & 2.0 \\
\hline PKRT & -20.0 & 19.6 & 0.3 & 0.3 & CJKT & -3.0 & 1.9 & 2.6 & 1.8 \\
\hline PPNJ & -19.7 & 19.3 & 0.3 & 0.3 & CJPR & -1.2 & 3.1 & 5.4 & 3.4 \\
\hline PRKB & -24.1 & 21.8 & 0.4 & 0.4 & CJUR & -7.1 & -0.8 & 6.9 & 4.3 \\
\hline PSKI & -2.6 & 10.3 & 0.3 & 0.3 & CLBG & -4.0 & 2.7 & 3.7 & 2.7 \\
\hline PSMK & 0.1 & 28.1 & 0.3 & 0.3 & CMIS & -8.4 & -1.8 & 4.3 & 2.9 \\
\hline PTLO & 5.1 & 22.8 & 0.3 & 0.3 & CMLP & -3.3 & 3.9 & 4.4 & 3.0 \\
\hline SLBU & -19.2 & 16.5 & 0.4 & 0.3 & CPBL & -0.5 & 0.3 & 4.2 & 3.1 \\
\hline SMGY & -17.0 & 17.6 & 0.4 & 0.3 & CPKL & -3.2 & 0.7 & 3.9 & 2.8 \\
\hline TLLU & -19.3 & 23.2 & 0.3 & 0.3 & CPSR & -2.6 & 5.2 & 3.7 & 2.6 \\
\hline
\end{tabular}


Table 2 (continuation)

\begin{tabular}{|c|c|c|c|c||c|c|c|c|c|}
\hline Site & $\begin{array}{c}E \\
{[\mathrm{~mm}]}\end{array}$ & $\begin{array}{c}N \\
{[\mathrm{~mm}]}\end{array}$ & $\sigma_{\mathrm{E}}$ & $\sigma_{\mathrm{N}}$ & Site & $\begin{array}{c}E \\
{[\mathrm{~mm}]}\end{array}$ & $\begin{array}{c}N \\
{[\mathrm{~mm}]}\end{array}$ & $\sigma_{\mathrm{E}}$ & $\sigma_{\mathrm{N}}$ \\
\hline TRTK & -6.6 & 9.5 & 0.3 & 0.3 & CPTU & -2.8 & 1.7 & 4.6 & 3.1 \\
UMLH & 141.1 & 90.0 & 0.7 & 0.8 & CPWK & 2.2 & 1.7 & 2.9 & 2.0 \\
CAIR & 12.6 & 9.9 & 3.4 & 2.4 & CRKS & 3.2 & 7.4 & 4.6 & 3.0 \\
CBKL & -10.9 & 9.5 & 3.9 & 2.2 & CROL & -0.6 & -0.1 & 2.9 & 2.0 \\
CBKT & 4.9 & 5.2 & 4.1 & 3.1 & CRUT & -3.2 & 6.0 & 5.4 & 3.5 \\
CPDG & -1.6 & 8.9 & 2.8 & 2.1 & CSUM & -3.3 & 3.2 & 4.3 & 2.9 \\
CSAB & 87.9 & 59.8 & 3.2 & 2.5 & CTAN & -1.9 & 1.9 & 5.0 & 3.2 \\
CTCN & -6.5 & 4.9 & 3.0 & 2.0 & CTGL & -3.2 & -1.0 & 3.8 & 2.7 \\
LHMI & 98.5 & 64.9 & 2.6 & 1.9 & JOGS & -1.5 & -0.1 & 3.4 & 2.5 \\
MEGO & -5.6 & 11.0 & 5.8 & 3.6 & HYDE & 2.1 & -7.8 & 2.8 & 2.3 \\
MEUL & 175.6 & 97.3 & 2.5 & 1.9 & IISC & 3.3 & -4.8 & 2.1 & 1.6 \\
\hline
\end{tabular}

Table 3

Misfit of data displacements to model

\begin{tabular}{|l|c|c|}
\hline Coseismic slip source & Data used for inversion & RMS \\
\hline Hayes (USGS) & Seismic & 28.10 \\
Yue et al. $(2012)$ & Seismic & 20.51 \\
Wei et al. $(2013)$ & Seismic & 17.47 \\
Hill et al. $(2015)$ & GPS + seismic & 12.33 \\
\hline
\end{tabular}

the GPS sites. We calculate the root mean square (RMS) between modeled and observed displacements to find the optimum coseismic model (Table 3).

\section{DISCUSSION}

Our study employs a spherical Earth model to calculate surface displacements at each GPS site. Other studies applied an elastic half-space model (Okada 1992), because it is much faster in terms of required calculation time (Piersanti et al. 1997). Unfortunately, the half-space model has limitations in areas far from the source, as the sphericity of the Earth starts playing role. To check the impact of using a half-space model for the far field region in Java, we calculate the H15 model using an elastic half-space model, yielding RMS of 22.17, a much higher misfit than that resulting from using spherical Earth analysis $(\mathrm{RMS}=12.33)$. This indicates that using a spherical Earth model to analyze far field deformation is much more appropriate than using a half-space model. 
This study suggests that the H15 model generates smaller misfit than the other models (Table 3), most likely because the H15 model uses joint inversion of seismic and geodetic data, while the other considered models use seismic data only. In another earthquake case, such as that of the $2004 \mathrm{Su}-$ matra-Andaman earthquake, Poisson et al. (2011) showed that a coseismic slip model derived from geodetic data better explains the recorded tsunami observed by satellite altimetry than a coseismic slip model derived from geological observation, tide gauge records, or other data.

In another example, considering the 2006 Java tsunami earthquake, Gunawan et al. (2016b) suggested that the coseismic fault slip model obtained from tsunami data better agrees with the postseismic deformation observed by GPS than with the other models obtained from seismic data. Although only one GPS site (BAKO), located at a remote distance, was active during the 2006 Java tsunami earthquake, modeled coseismic displacements from data BAKO detected during the 2006 event were about $2.5 \mathrm{~mm}$, which fits to the tsunami data better than the other models.

To summarize our investigation of the 2012 Indian Ocean earthquake, we showed that analysis of coseismic slip during earthquake occurrences obtained from a single type of observation, namely seismic data, poorly fits the GPS measurements. Similar results have been found in various other studies which only use seismic data with coseismic slip models, such as the study of the 2004 Sumatra-Andaman earthquake by Poisson et al. (2011). Instead, using multiple observations, such as seismic, geodetic, or tsunami data, as also shown by Hill et al. (2015) and Rhie et al. (2007), generates better results than using a single type of observation.

\section{CONCLUSIONS}

We analyzed the coseismic slip of the 2012 Indian Ocean earthquake based on the H12, Y12, W13, and H15 models. We used coseismic offsets obtained from GPS measurements in Andaman-Nicobar, Sumatra and Java, comparing these offsets to the modeled coseismic displacements from the available slip models using a spherical, layered model of the Earth. We find that Java Island experienced coseismic deformation of up to $8 \mathrm{~mm}$, as observed by our GPS network. Our results suggest that a coseismic slip model obtained from multiple observations of seismic and geodetic data - the H15 model - produced less misfit than the coseismic slip models obtained using a single type of observation (from a seismic network).

Acknowledgments. We thank Vineet K. Gahalaut, two anonymous reviewers, and the Editor for the constructive suggestions, which helped to improve the quality of this manuscript. This research was partially funded by the Australian Department of Foreign Affairs and Trade (DFAT) for Gradu- 
ate Research on Earthquake and Active Tectonics at the Bandung Institute of Technology and the World Class University Research Fund from the Bandung Institute of Technology. We thank Fred Pollitz for making STATIC1D code freely available. Figures were generated using the Generic Mapping Tool software (Wessel and Smith 1998).

\section{References}

Alif, S.M., I. Meilano, E. Gunawan, and J. Efendi (2016), Evidence of postseismic deformation signal of the 2007 M8.5 Bengkulu earthquake and the 2012 M8.6 Indian Ocean earthquake in Southern Sumatra, Indonesia, based on GPS data, J. Appl. Geod. 10, 2, 103-108, DOI: 10.1515/jag-2015-0019.

Altamimi, Z., X. Collilieux, and L. Métivier (2011), ITRF2008: an improved solution of the international terrestrial reference frame, J. Geod. 85, 8, 457-473, DOI: 10.1007/s00190-011-0444-4.

Anugrah, B., I. Meilano, E. Gunawan, and J. Efendi (2015), Estimation of postseismic deformation parameters from continuous GPS data in northern Sumatra after the 2004 Sumatra-Andaman earthquake, Earthq. Sci. 28, 5-6, 347352, DOI: 10.1007/s11589-015-0136-x.

Ardika, M., I. Meilano, and E. Gunawan (2015), Postseismic deformation parameters of the 2010 M7.8 Mentawai, Indonesia, earthquake inferred from continuous GPS observations, Asian. J. Earth Sci. 8, 4, 127-133, DOI: 10.3923/ ajes.2015.127.133.

Delescluse, M., N. Chamot-Rooke, R. Cattin, L. Fleitout, O. Trubienko, and C. Vigny (2012), April 2012 intra-oceanic seismicity off Sumatra boosted by the Banda-Aceh megathrust, Nature 490, 7419, 240-244, DOI: 10.1038/ nature 11520.

Duputel, Z., H. Kanamori, V.C. Tsai, L. Rivera, L. Meng, J.P. Ampuero, and J.M. Stock (2012), The 2012 Sumatra great earthquake sequence, Earth Planet. Sci. Lett. 351, 247-257, DOI: 10.1016/j.epsl.2012.07.017.

Feng, L., E.M. Hill, P. Banerjee, I. Hermawan, L.L. Tsang, D.H. Natawidjaja, B.W. Suwargadi, and K Sieh (2015), A unified GPS-based earthquake cata$\log$ for the Sumatran plate boundary between 2002 and 2013, J. Geophys. Res. Solid Earth 120, 5, 3566-3598, DOI: 10.1002/2014JB011661.

Gunawan, E., T. Sagiya, T. Ito, F. Kimata, T. Tabei, Y. Ohta, I. Meilano, H.Z. Abidin, I. Agustan, I. Nurdin, and D. Sugiyanto (2014), A comprehensive model of postseismic deformation of the 2004 Sumatra-Andaman earthquake deduced from GPS observations in northern Sumatra, J. Asian Earth Sci. 88, 218-229, DOI: 10.1016/j.jseaes.2014.03.016.

Gunawan, E., M. Kholil, and I. Meilano (2016a), Splay-fault rupture during the 2014 Mw7. 1 Molucca Sea, Indonesia, earthquake determined from GPS measurements, Phys. Earth Planet. Int. 259, 29-33, DOI: 10.1016/j.pepi. 2016.08.009. 
Gunawan, E., I. Meilano, H.Z. Abidin, N.R. Hanifa, and Susilo (2016b), Investigation of the best coseismic fault model of the 2006 Java tsunami earthquake based on mechanisms of postseismic deformation, J. Asian Earth Sci. 117, 64-72, DOI: 10.1016/j.jseaes.2015.12.003.

Gusman, A.R., S. Murotani, K. Satake, M. Heidarzadeh, E. Gunawan, S. Watada, and B. Schurr (2015), Fault slip distribution of the 2014 Iquique, Chile, earthquake estimated from ocean-wide tsunami waveforms and GPS data, Geophys. Res. Lett. 42, 4, 1053-1060, DOI: 10.1002/2014GL062604.

Hanifa, N.R., T. Sagiya, F. Kimata, J. Efendi, H.Z. Abidin, and I. Meilano (2014), Interplate coupling model off the southwestern coast of Java, Indonesia, based on continuous GPS data in 2008-2010, Earth Planet. Sci. Lett. 401, 159-171, DOI: 10.1016/j.epsl.2014.06.010.

Herring, T.A., R.W. King, and S.C. McClusky (2010a), GAMIT reference manual release 10.4, Report, Massachusetts Institute Technology, Cambridge, USA, $171 \mathrm{pp}$.

Herring, T.A., R.W. King, and S.C. McClusky (2010b), GLOBK reference manual: global Kalman filter VLBI and GPS analysis program release 10.4, Report, Massachusetts Institute Technology, Cambridge, USA, 95 pp.

Hill, E.M., H. Yue, S. Barbot, T. Lay, P. Tapponnier, I. Hermawan, J. Hubbard, P. Banerjee, L. Feng, D. Natawidjaja, and K. Sieh (2015), The $2012 \mathrm{Mw}$ 8.6 Wharton Basin sequence: A cascade of great earthquakes generated by near-orthogonal, young, oceanic mantle faults, J. Geophys. Res. Solid Earth 120, 5, 3723-3747, DOI: 10.1002/2014JB011703.

Ito, T., E. Gunawan, F. Kimata, T. Tabei, M. Simons, I. Meilano, I. Agustan, Y. Ohta, I. Nurdin, and D. Sugiyanto (2012), Isolating along-strike variations in the depth extent of shallow creep and fault locking on the northern Great Sumatran Fault, J. Geophys. Res. Solid Earth 117, B6, B06409, DOI: 10.1029/2011JB008940.

Ito, T., E. Gunawan, F. Kimata, T. Tabei, I. Meilano, I. Agustan, Y. Ohta, N. Ismail, I. Nurdin, and D. Sugiyanto (2016), Co-seismic offsets due to two earthquakes (Mw6.1) along the Sumatran fault system derived from GNSS measurements, Earth Planet. Space 68, 57, DOI: 10.1186/s40623-0160427-z.

Meilano, I., E. Gunawan, D. Sarsito, K. Prijatna, H.Z. Abidin, and J. Efendi (2015), Preliminary deformation model for National Seismic Hazard map of Indonesia, AIP Conf. Proc. 1658, 030003, DOI: 10.1063/1.4915011.

Meng, L., J.P. Ampuero, J. Stock, Z. Duputel, Y. Luo, and V.C. Tsai (2012), Earthquake in a maze: Compressional rupture branching during the $2012 \mathrm{Mw} 8.6$ Sumatra earthquake, Science 337, 6095, 724-726, DOI: 10.1126/science. 1224030.

Ohkura, T., T. Tabei, F. Kimata, T.C. Bacolcol, Y. Nakamura, A.C. Luis, A. Pelicano, R. Jorgio, M. Tabique, M. Abrahan, E. Jorgio, and E. Gunawan (2015), Plate convergence and block motions in Mindanao Island, Philip- 
pine as derived from campaign GPS observations, J. Disaster Res. 10, 1, 59-66, DOI: 10.20965/jdr.2015.p0059.

Okada, Y. (1992), Internal deformation due to shear and tensile faults in a halfspace, Bull. Seismol. Soc. Am. 82, 2, 1018-1040.

Piersanti, A., G. Spada, and R. Sabadini (1997), Global postseismic rebound of a viscoelastic Earth: Theory for finite faults and application to the 1964 Alaska earthquake, J. Geophys. Res. 102, B1, 477-492, DOI: 10.1029/ 96JB01909.

Poisson, B., C. Oliveros, and R. Pedreros (2011), Is there a best source model of the Sumatra 2004 earthquake for simulating the consecutive tsunami?, Geophys. J. Int. 185, 3, 1365-1378, DOI: 10.1111/j.1365-246X.2011.05009.x.

Pollitz, F.F. (1996), Coseismic deformation from earthquake faulting on a layered spherical Earth, Geophys. J. Int. 125, 1, 1-14, DOI: 10.1111/j.1365-246X. 1996.tb06530.x.

Raharja, R., E. Gunawan, I. Meilano, H.Z. Abidin, and J. Efendi (2016), Long aseismic slip duration of the 2006 Java tsunami earthquake based on GPS data, Earthq. Sci., DOI: 10.1007/s11589-016-0167-y.

Rhie, J., D. Dreger, R. Bürgmann, and B. Romanowicz (2007), Slip of the 2004 Sumatra-Andaman earthquake from joint inversion of long-period global seismic waveforms and GPS static offsets, Bull. Seismol. Soc. Am. 97, 1, S115-S127, DOI: 10.1785/0120050620.

Tabei, T., F. Kimata, T. Ito, E. Gunawan, H. Tsutsumi, Y. Ohta, T. Yamashina, Y. Soeda, N. Ismail, I. Nurdin, D. Sugiyanto, and I. Meilano (2015), Geodetic and geomorphic evaluations of earthquake generation potential of the northern Sumatran fault, Indonesia. In: International Association of Geodesy Symposia, Springer, Berlin Heidelberg, DOI: 10.1007/1345_2015_200, 1-8.

Wei, S., D. Helmberger, and J.P. Avouac (2013), Modeling the 2012 Wharton basin earthquakes off-Sumatra: Complete lithospheric failure, J. Geophys. Res. Solid Earth 118, 7, 3592-3609, DOI: 10.1002/jgrb.50267.

Wessel, P., and W.H.F. Smith (1998), New, improved version of the generic mapping tools released, Eos Trans. $A G U$ 79, 47, 579, DOI: 10.1029/ 98EO00426.

Yadav, R.K., B. Kundu, K. Gahalaut, J. Catherine, V.K. Gahalaut, A. Ambikapthy, and M.S. Naidu (2013), Coseismic offsets due to the 11 April 2012 Indian Ocean earthquakes (Mw 8.6 and 8.2) derived from GPS measurements, Geophys. Res. Lett. 40, 13, 3389-3393, DOI: 10.1002/grl.50601.

Yue, H., T. Lay, and K.D. Koper (2012), En echelon and orthogonal fault ruptures of the 11 April 2012 great intraplate earthquakes, Nature 490, 7419, 245249, DOI: 10.1038/nature11492. 